\title{
Endeavours towards Academic Success: An Investigation of Underprivileged Student's Life Experience
}

\author{
Jeson Jacinto Galgo ${ }^{1}$

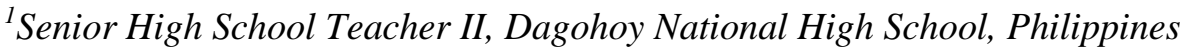

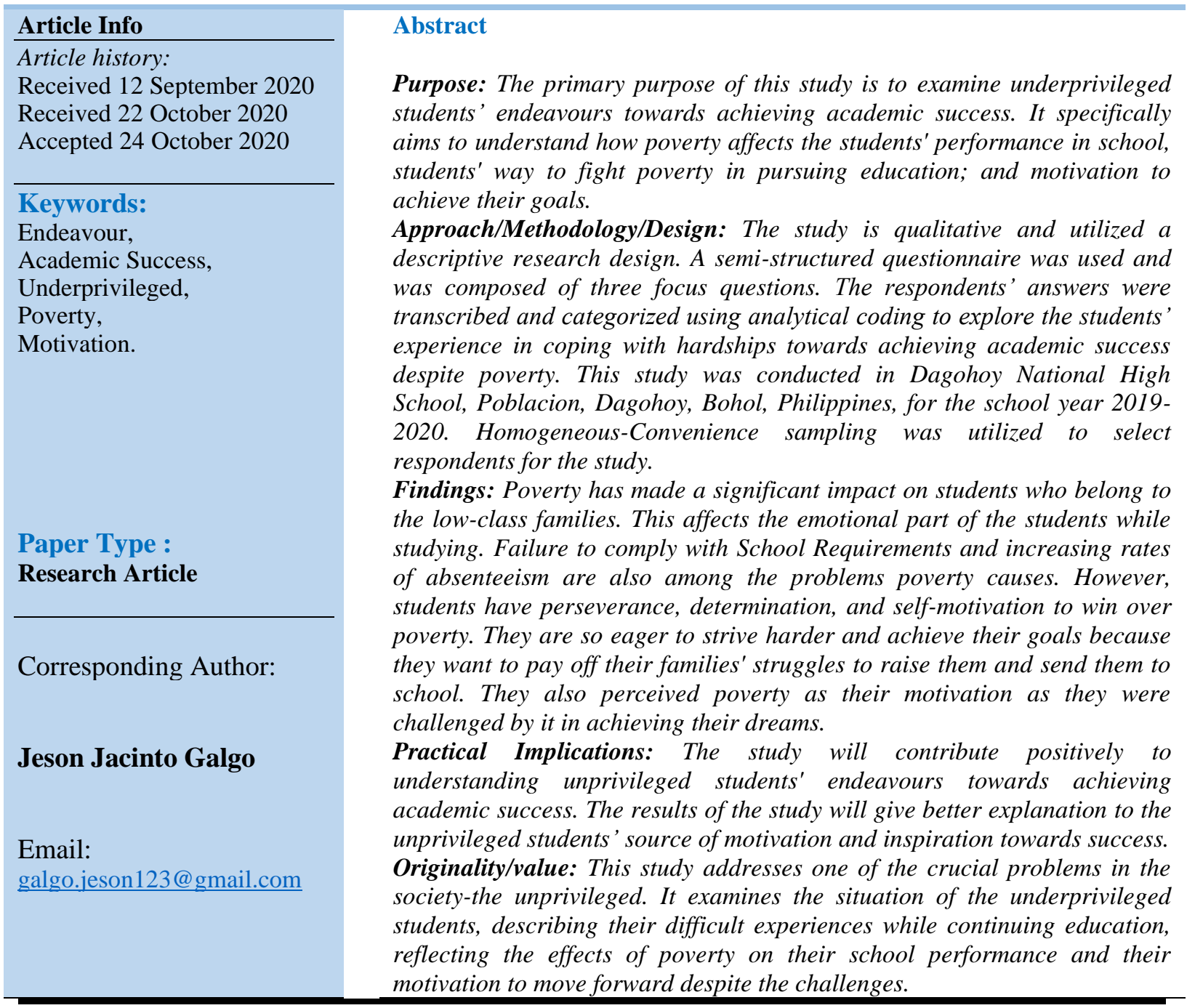

\section{Introduction}

Determination is one of the attitudes a student must possess. It is essential to maintain selfdetermination to achieve one's goal in life. If a student doesn't have perseverance in life, he/she won't accomplish the plans at the same time. Poverty is one of the major problems that many families face today. Students are usually the ones to get greatly affected by this arising issue. As we all know, poverty is not a hindrance to succeed because the one who's willing to 
learn and is determined to acquire new knowledge always finds away. Winning over poverty is not an easy task. It takes a lot of courage, hardships, dedication, and perseverance to succeed.

Students who are determined in overcoming poverty had the perseverance to study and a strong will in achieving goals is the respondents of this study (Kalil et al., 2014). Even if it is not a walking distance, a student who walked to school still managed to do so since they can't afford to pay the vehicular services. In response, a framework for understanding students in poverty has been created and embraced by the school districts all over the country. Payne, R. K. (1995) has been one such developer and has described poverty as a culture in which specific rules are set. She has suggested that educational institutions operate from a middleclass set of norms and fail to communicate to students in poverty through how they understand. Her work has been critiqued and viewed by some as stereotypical and bigoted, having no valid research to confirm her claims.

Over the years, poverty is still the leading problem in Dagohoy, a $5^{\text {th }}$ class municipality in terms of income classification in the province of Bohol, Philippines (Provincial Government of Bohol, 2019-2020). As noted, poverty is a significant and growing problem for the Philippines leaving low-income families and individuals with a significantly reduced chance of achieving the Filipino dream. The impact of poverty on education is significant. The educator's role has increasingly changed as research shows that students in poverty are less receptive to traditional teaching methods (Darling-Hammond, 2001). Today, most of the students experience this kind of situation. It is in this direction that this research paper is conducted to investigate the different factors that influence the student's determination and willingness to fight over poverty. It aims to encourage the students to continue pursuing their dreams based on their sentiments regarding studying despite the situation. This study's primary purpose is to understand underprivileged students' endeavour towards achieving academic success in Dagohoy National High School, Bohol, Philippines. Specifically, the following focus questions will be used as a guide to answer the general objective of the study: (1) How poverty could affect student's performance in school?; (2) How do students fight poverty as to the pursuit of their education?; and (3) What are the students' motivations in achieving their goals?

\section{Literature Review}

This study is based on the Self-Determination Theory and Arc's Model of Motivational Design Theory. Research by psychologists Ryan, R. M. and Deci, E. L. (2000) on SelfDetermination Theory indicates that motivations (doing something because it is inherently interesting or enjoyable), thus higher quality learning flourish in contexts that satisfy human needs for competence, autonomy, and relatedness. Students experience competence when challenged and given prompt feedback (American Psychological Association, 2004). They experience freedom when they feel support to explore, take the initiative, and develop and 
implement solutions for their problems. Relatedness will also be experienced when they perceive others are listening and responding to them. When these three needs are met, Students are more intrinsically motivated and actively engaged in their learning.

Numerous studies have found that students who are more involved in setting educational goals are more likely to reach their goals. When students perceive that the primary focus of learning is to obtain external rewards, such as a grade on an exam, they often perform more poorly and report more significant anxiety than when they believe that exams are simply a monitor for their learning (Ryan\& Deci, 2000). According to John Keller's ARCS Model of Motivational Design Theories, there are four steps for promoting and sustaining motivation in the learning process: Attention, Relevance, Confidence, and Satisfaction. Similarly, Penna, A. G. (2001) considers motivation as the study of the object of psychology, and the various theories are derived from four main movements: behavioural, cognitive, psychoanalytic, and humanistic. The SDT builds on the principle of evaluating different manifestations of motivation that may be involved in the teaching and learning process.

Lifegist (2013) states that the financial problems cause various effects on the educational sector. The increasingly exorbitant cost of formal education constitutes the primary excuse most parents or guardians give for not educating or withdrawing their children and wards from school to learn a trade. They do not bother to put or contribute their money to the education of their children. Some students, for financial reasons, could not pay attention in the class. Instead, they would be thinking of getting money to buy their valuable materials, handouts, etc.

According to Jones, M. (2016), motivation transforms goals into actions. If the students have the motivation, they will find themselves working towards their dreams because they are inseparable. If they are less motivated, chances are that they will be crawling forward like a turtle. In the same vein, Farah, M. J., Noble, K. G., and Hurt, H. (2007) believe that SocioEconomic Status (SES) affects physical health through a few different causal pathways which could play a role in the brain development. It is also clear that poverty is associated with differences in brain function. Furthermore, Rao, H. B. (2010) states that "the unique predictive value of parental nurturance at age 4 suggests a more important role for warm parental care over cognitive stimulation for normal hippocampal development, especially during early childhood years". Crowder, A. and South, B. (2003) suggested that the family's socio-economic status wields a significant influence on the likelihood that students will attend school irregularly. Students who reside in urban neighbourhoods are more likely to miss school and become chronically absent due to the myriad factors that distract students.

Ginsburg, G. and Bronstein, P. (2003) states that Parental encouragement in response to grades children received was associated with an intrinsic motivational orientation, and autonomy-supporting family styles were associated with intrinsic motivation and higher academic performance. It is also added that the socioeconomic level was a significant 
predictor of motivational orientation and academic performance. According to Avenell, C. A. (2009), the failure of traditional poverty reduction programs to achieve deeper outreach to the very poor is a growing concern, as evidenced by the United Nations Millennium Development Goals (MDGs), which envision extreme poverty to be halved by 2015. Meyer, B. D., and Sullivan, J. X. (2010) conclude their study "Winning the War: Poverty from the Great Society To The Great Recession" that their preferred consumption-based poverty measure shows significant improvement since the mid-1980 while income-based poverty shows little progress. They argue that consumption-based poverty measures are chosen over income-based action because the latter are biased by the underreporting of government transfers, which appears to have worsened over time. Additionally, they argue that consumption is preferable because it is closer to permanent income, and those classified as income-poor.

Baker, B. and Coley, R. (2013) pointed in their study "Poverty and Education: Finding the Way Forward" that research on state schools finance reforms supports this contention. A significant body of state-specific studies shows that changes to the level and distribution of available resources can influence changes to the class and distribution and student outcomes. According to Allen, J. (2013), abject poverty can be eradicated if an enabling environment for learning is put in place. The poverty cycle can be broken, and the way is through education. Based on his conclusion, to break the process, we must provide education for the most impoverished children. Furthermore, it will be necessary to generate new knowledge about the children-where to find them, their characteristics, and their needs-so those education policies, plans, and program implementation can be better informed.

In the study of Oriahi, C. I. and Aitufe, A. O. (2010) entitled "Education for the Eradication of Poverty", it is revealed that poverty has not only to compromise the lives of a countless number of children and adult but jeopardized the future of the very society in which they live. Subsequently, it is essential to understand that the measures of eradication of poverty are numerous and varied in their manifestation. As a result, there is the need for an integrated approach to remove the causes and eradicate poverty to pave the way for a decent society free from anti-social behaviours, which are the resultant effects of poverty. Nonetheless, education is pivotal in breaking the vicious cycle of poverty, and social segregation is the reality for many people.

Education is vital for poverty reduction. In their research study "Poverty Reduction through Education", Ducanes and Tan (2014) indicate that poverty incidence drops to $2.4 \%$ in a household with at least one college graduate. Thus, getting a college degree is essential, with a $98 \%$ poverty reduction indicator in the Philippines. Reyes, C. M., and Valencia, L. E. (2004) concluded in their study "Poverty Reduction Strategy and Poverty Monitoring: Philippine case Study" that the Philippines' performance concerning poverty reduction has been very modest. While poverty incidence has declined over the past 15 years, the number of poor has increased. Based on the literature reviewed, reducing poverty should be 
accompanied by a sound poverty monitoring system. Poverty monitoring provides government planners, policymakers, and local leaders with data to base their social and economic development plans and programs.

\section{Methodology and Procedures}

This case study has utilized a descriptive research design. According to Mitchell, a case study is a detailed examination of an event (or series of related events) which the analyst believes exhibits the operation of some identified general theoretical principle. It is descriptive in the sense that the researcher tends to describe and analyze students' endeavours towards academic success despite poverty. The respondents' answers were transcribed and categorized using analytical coding to explore the students' experience in coping with hardships towards achieving academic success despite poverty.

This study was conducted in Dagohoy National High School, Poblacion, Dagohoy, Bohol, Philippines, for the school year 2019-2020. Homogeneous-Convenience sampling was utilized to select respondents for the study. Homogeneous sampling is a purposive sampling technique that aims to achieve a homogeneous sample; that is, a sample whose units share the same (or very similar) characteristics or traits (Laerd, 2012). This sampling technique fits to this study as the researcher has purposely selected respondents based on their 4Ps membership (Pantawid Pamilya Pilipino Program), a program granted by the Philippine Government for the poor Filipino families. Convenience sampling on the other hand, as the researcher only consider those available qualified respondents during the actual gathering of data. As stated by Saunders, M., Lewis, P. and Thornhill, A. (2012), convenience sampling is a specific type of non-probability sampling method that relies on data collection from population members who are conveniently available to participate in study.

A semi-structured questionnaire was used in the study, and to guarantee a more extended response from the respondents, follow-up and probing questions were exercised during the actual interview. The questionnaire is composed of three focus questions. The first one focuses on how poverty affects the student's performance in school; the second one focuses on how students fight poverty to pursue their education. The third one focuses on the students' motivations in achieving their goals.

\section{Results and Discussion}

The research questions for this study - How poverty could affect students' performance in school? ; How do students find solutions in fighting poverty in pursuing their education?; and What are the students' motivations in achieving their goals? - led the researcher to develop interview questions about students' sentiments on how poverty affects their performance in school; solutions in fighting against poverty as to the pursuit of their education; and their great motivations in achieving their goals. To understand the effects of poverty fully, the researcher carefully analyses the students' answers, leading the findings as reflected below. 
All names appeared in this section are just pseudonym, thus respondents' personal information was confidentially secured.

\section{Effects of poverty on students' performance in school}

Under this focus problem, the researcher has come up with the following sub-themes: Financial Incapability, Emotional aspect, Failure to comply with school activities, and absenteeism.

\section{Financial Incapability}

Some people are striving hard each day to raise money to support their families, students that are seeking capital to advocate for their studies and the likes. One of the problems that the students are facing in their studies is the school fees or contributions. Most of the students can hardly pay their fees in school due to their families' financial incapability.

As Bea stated:

“Kanang mag kuan, maglisud ug kuan bayad ug tampuhon sa eskwelahan.”

Translation: "I can hardly pay the contributions in school."

It was shown that a poverty-stricken student couldn't easily sustain his/her needs in school, not even her contributions. Hence, poverty has made a significant impact on students, especially to the students who belong to the low-class families with regards to their studies.

Agatha said:

"Kanang naay mga project ug naay mga tampuhon sa eskwelahan kana pong naay mga kinahanglan i-research nga mga assignment, di ko ka assignment."

Translation: "I could hardly make my assignments and projects in school

Students were given requirements to comply and submit in each period as a requisite for them to pass; otherwise they will fail in that specific subject. Thus, poverty could undoubtedly affect their performance in school.

The increasingly exorbitant cost of formal education constitutes the primary excuse most parents or guardians give for not educating or withdrawing their children and wards from school to learn a trade. They do not bother to put or contribute their money to the education of their children. Some students, for financial reasons, could not pay attention in the class. Instead, they would be thinking of getting money to buy their functional materials, handouts, etc. Thus, it is clearly stated that Financial Incapability is one of the problems students face in their studies. 


\section{Emotional Aspect}

Poverty could affect students' emotional aspects. They could feel upset every time they think of the needs that they have to attend to. Because of being financially incapable, their needs cannot be fulfilled. Students indeed need their family's support, as Dennise stressed:

“...broken family baya ko unya usahay nagkinahanglan pami ug supporta jud sa ginikanan unya mao nang jud naglisod pud mi usahay pud."

Translation: “...I'm a product of a broken family; we still need support from our parents that is why sometimes we've experienced difficulties".

It is clearly stated that students need both financial and emotional support from their families According to Farah, Noble, and Hurt (2007), Socio-Economic Status (SES) affects physical health through several different causal pathways, many of which could play a role in brain development. It is also clear that poverty is associated with a difference in brain function. It was evident that poverty can affect physical health that may also lead to students' brain function.

\section{Failure to comply with School Requirements and Absenteeism}

Students in school sometimes need considerations, especially in times that they must take the exam and pay their school fees. As Eunice concerned:

"Ah naa parehas adtong test sa pag grade 8? Grade 9? basta test to sya, periodical test final na to sya, final fourth grading unya bisag piso, walang-wala jud mi adto, wala na pud koy papa adto pong timema ahong lola pud nasakit maong dili mi makapangayo ug tabang sa ahong lola unya mao tong nagpromise gyud ko adto, nagbinagag dung sa principal.”

Translation: "Yes, like when we have a final exam before, then I don't have penny even a centavo, we really have nothing at that time, my father had passed away, and my grandmother was sick, that's why we don't have someone to help. So, I just make myself brave to go and beg to school principal to just let me make a promissory note."

If students are not given considerations, they will probably not take the exams since they cannot pay their school obligations on time. Without assigning references, it could result in students to skip their classes to remediate their needs by seeking sidelines, as Clarisse said:

"Usahay sigeg absent kay mananom, unya wa bitaw ug kwarta."

Translation: "Sometimes, I have to be absent in class just to work in the farm so I could save money."

Generally, the effects of poverty on students' performance is rampant, it can be through the students' Financial Incapability, Emotional Aspect, and Failure to comply with School 
Requirements and Absenteeism. Crowder and South (2003) suggested that the family's socioeconomic status wields a significant influence on the like hood that students will attend school irregularly. Students who reside in urban neighbourhoods are more likely to miss school and become chronically absent due to the myriad factors that distract students. As supported by UNESCO (2000), in urban areas, school attendance is often these times more excellent than in rural areas. In addition, in rural day-secondary schools students have difficulties in buying necessary materials that contribute to learning. Besides, absence from school negatively affects the performance of students in these schools. These eventually affect the performance of day-secondary schools in rural areas.

Family's socio-economic status is undeniably one of the reasons why students irregularly attend school. Due to financial incapability, students' absenteeism becomes chronic. Thus, their school performance gets affected.

\section{Students' Solutions in fighting against poverty as to the pursuit of their education}

Students encounter obstacles on their way to achieving their goals. Learning how to overcome these obstacles teaches us perseverance. There are many times in life that they feel like giving up. It is essential to recognize their goal. It is unusual to accomplish it on the first attempt, but they must begin by taking actions toward their goal. It will most likely take several attempts to use a variety of different methods to see progress. It may take two, three, five, and even ten tries, but being able to persevere, focus, and re-focus again and again on the end goal increases the likelihood that goals will be accomplished.

All success requires the ability to follow through, execute a plan, persevere, and stick with it. Perseverance comes down to make decisions and not to give up. Through poverty, students learned to be self-dependent people. They do jobs that they think can support their education.

As what Agatha stated:

"Nag working ko kanang mo mata kog sayo kay naa pa koy trabahoon, nanilhig, manghugas nya maligo pud ko. Naay usahay ma late ko ug anhi sa skwelahan."

Translation: "I'm a working student, I need to wake up early in the morning to do household chores even sometimes I came late at school."

Added by Clarise:

“Working student ko, mo mata kog sayo para dili ma late."

Translation: "I'm a working student; I need to wake up early so that I will not be late at school."

Moreover, Eunice said: 
"Maningkamot unya dili mag inOA. Kanang maningkamot siya, kanang naa kay determinasyon para makahuman sa pag skwela. Ga working ko sa ahong auntie dako kaayog katabang."

Translation: "You need to work hard then don't act overacting. Work hard and be determined to finish studies. Actually, I am currently working at my aunt and it helped me so much."

Students were very determined enough to achieve their goals and pursue their dreams to the extent they consider working while studying as the only way to win over poverty. Generally, students use perseverance, determination, and self-motivation as a weapon to fight poverty regarding their education. According to Matthew Jones (2016), motivation transforms goals into actions. If you have the motivation, you will find yourself working towards your dreams because they are inseparable. If you are less motivated, chances are, you'll be crawling forward like a turtle (Jones, 2016). Thus, if motivation has existed in life, there is an excellent possibility that anyone will successfully achieve the goals. On the contrary, with less stimulation, meeting the plans may be a difficult way to go.

\section{Students' Motivation in Achieving Goals}

\section{Family}

Everybody has the motivation to achieve their goals. However, students need an inspiration that will build and encourage students to strive harder. In school, students were motivated in different ways, and one of those was their family. Family is a vital factor in motivating students to perform well and, most significantly, to persuade them to achieve their goals.

As Agatha stressed:

"Ahong pamilya, kay di ko kanang ganahang maagian nila sa tibuok kinabuhi ang kalisod."

Translation: "My family, because I don't want them to experience forever the difficulty out from poverty."

Bea added:

"Pamilya, kay aron maka baws sa ilang gibuhat. Aron makabaws sa ilang kahago nga gibuhat para nako."

Translation: "Family, so that I could give back to the things they've done for me. To give back the hardships that they have endured for me."

It was evident that students are motivated by their family not because they were encouraged by them, but because they want to help their family overcome poverty. And most 
importantly, they want to pay off their family's struggles and hardships to raise them and send them to school. Golda S. Ginsburg and Phyllis Bronstein (2003) stated that Parental encouragement in response to grades children received was associated with an intrinsic motivational orientation, and autonomy-supporting family styles were associated with intrinsic motivation and higher academic performance. Thus, family motivation is acknowledged as an intrinsic motivation for students that may lead to good school performance. With them, despite the difficulty, students will strive hard to succeed. That is how family support and school engagement are important factors for students' academic success.

\section{Poverty}

Students also perceived poverty as one of their motivation to strive harder because they want to make their lives better than before. And they were also challenged by it to beat poverty successfully and to overcome it gradually.

As Eunice said:

"Usa ana amoang kinabuhi, galisod mi unya gusto naho matabangan ahong mama nga dili na maglisod unya gusto ko dili na maka experience ahoang mga mahimong anak puhon unya pareha sa na experience sauna, makatabangan naho sila."

Translation: "We had endured enough difficulties in our life, and I don't want my future family to experience what I had experienced."

Students were motivated through poverty because they want to make a change in their lives to make it better and comfortable. Hence, motivation plays an essential role in students' goal attainment. Golda S. Ginsburg and Phyllis Bronstein (2003) added that Socioeconomic Level was a significant predictor of motivational orientation and academic performance. Therefore, the socio-economic level was considered a great predictor to motivate students to pursue their dreams. No matter what their status is, poverty cannot stop them from achieving their goals. Generally, family and poverty serve as students' great motivation in achieving their goals.

\section{Conclusion and Suggestion}

It is concluded that poverty has makes a significant negative impact on students' academic performance, especially on those who belong to the low-class families with regards to their academic aspect. Poverty could also affect the emotional part of the students while they are studying. Moreover, Failure to comply with School Requirements and increasing rates of students' absenteeism are associated with poverty and financial incapability. Nevertheless, students showed considerable perseverance, determination, and self-motivation as their weapon in fighting poverty to achieve academic success. Family is one of the motivations the students have in moving forward. The participants of the study were so eager to strive harder and achieve their goals because they want to pay off their families' struggles to raise them 
and send them to school. Moreover, students have also perceived poverty as their motivation as they were challenged by it in achieving their dreams and not to experience it in the future.

It is recommended that students be optimistic enough to deal with things that they could encounter along the way. They should not consider financial incapability as a block on their way, but instead, they should be wise and determined enough to initiate alternative ways to achieve their goals. More importantly, teachers should consider the students, especially in times when they cannot pay fees and contributions. Guidance counselling is highly recommended for the students to cope with their emotional stress brought up by poverty, and parents must support their children.

\section{Acknowledgments}

The researcher would like to express his heartfelt gratitude to Almighty God for sustaining the researcher with His graces during the times that he was still constructing this work until its completion. To the researcher's family for endless motivation and inspiration. To the respondents who have given their time wholeheartedly for the one-on-one interview. And lastly, to those who have not mentioned here but in one way or another willingly and generously helped in accomplishing this study.

\section{Conflict of Interest}

The author of the article declares no conflict of interest.

\section{Funding}

This research was not funded by any institution. The author conducted the study on his own expenses.

\section{References}

Allen, J. Ed. (2003). Poverty Eradication through Education. Uganda National commission for UNESCO, Ministry of education. Retrieved from http://unesdoc.unesco.org.pdf

American Psychological Association. (2004). Increasing student success through instruction in self-determination. Accessed online at http://www. apa. org/research/action/ success. aspx Feb, 8, 2012.

Avenell, C. A. (2009). Literature review on poverty reduction strategies aimed at the very poor. Retrieved from www.seepnetwork.org/literature-review-on-poverty-reductionstrategies-aimed-at-the-very-poor-resources-524.php

Coley, R. J., \& Baker, B. (2013). Poverty and education: Finding the way forward. Educational Testing Service Center for Research on Human Capital and Education.

Crowder, A. \& South B. (2003). Contributing factors to absenteeism. Retrieved from https://www.doe.in.gov/student-services/attendance/contributing-factors-absenteeism.

Darling-Hammond, L. (2001). Inequality in teaching and schooling: How opportunity is 
rationed to students of color in America. BD Smedley, AY Stith, L. Colburn, C. \& H. Evans (Eds.), The right thing to do-The smart thing to do, 208-233.

Deci, E. L., Koestner, R., \& Ryan, R. M. (1999). A meta-analytic review of experiments examining the effects of extrinsic rewards on intrinsic motivation. Psychological bulletin, 125(6), 627.

Ducanes\& Tan (2014). Poverty reduction through education. Retrieved from http://www.veritas 847.ph/povert-reduction-education/

Farah, M. J., Noble, K. G., \& Hurt, H. (2006). Poverty, privilege, and brain development: Empirical findings and ethical implications. Neuroethics: Defining the issues in theory, practice, and policy, 277-288.

Ginsburg, G. S., \& Bronstein, P. (1993). Family factors related to children's intrinsic/extrinsic motivational orientation and academic performance. Child development, 64(5), 14611474.

Jones, M. (2016). The ultimate way to increase students' motivation. Retrieved from https:/www.inc.com/matthew-jones/the-ultimate-way-to-increase-motivation.html

Kalil, A., Yoshikawa, H., \& Ziol-Guest, K. M. (2014). Developmental psychology and poverty in global contexts: The role of the family. Barriers to and Opportunities for Poverty Reduction, 22.

Keller, J. M. (1987). Development and use of the ARCS model of instructional design. Journal of instructional development, 10(3), 2.

Lifegist (2013). Financial incapability affecting students' performance in school. Retrieved from https://www.edu.gov

Matsuura, K. (2007). Ending poverty through education. UN Chronicle, 44(4), 21-22.

Meyer, B. D., \& Sullivan, J. X. (2013). Winning the war: Poverty from the Great Society to the Great Recession (No. w18718). National Bureau of Economic Research.

Oriahi, C. I., \& Aitufe, A. O. (2010). Education for the Eradication of Poverty. Current Research Journal of Social Sciences, 2(6), 306-310.

Payne, R. K. (2019). A framework for understanding poverty: A cognitive approach (p. 248). Aha! Process, Incorporated.

Provincial Government of Bohol (2019-2020). Municipality of Dagohoy. Retrieved from https://bohol.gov.ph/dagohoy/

Rao, H., Betancourt, L., Giannetta, J. M., Brodsky, N. L., Korczykowski, M., Avants, B. B., ... \& Farah, M. J. (2010). Early parental care is important for hippocampal maturation: evidence from brain morphology in humans. Neuroimage, 49(1), 1144-1150.

Reyes, C., \& Valencia, L. (2004). Poverty reduction strategy and poverty monitoring: Philippine case study. In Regional Conference On Poverty Monitoring In Asia. Mandaluyong: Cepa.

Ryan, R. M., \& Deci, E. L. (2000). Self-determination theory and the facilitation of intrinsic motivation, social development, and well-being. American psychologist, 55(1), 68.

Thornhill, A., Saunders, M., \& Lewis, P. (2009). Research methods for business students. Essex: Pearson Education Ltd.

Copyright (C) 2020, Middle Eastern Journal of Research in Education and Social Sciences (MEJRESS), Under the license CC BY-SA 4.0 
Wadsworth, M. E., Raviv*, T., Reinhard, C., Wolff, B., Santiago, C. D., \& Einhorn, L. (2008). An indirect effects model of the association between poverty and child functioning: The role of children's poverty-related stress. Journal of Loss and Trauma, 13(2-3), 156-185. 